\title{
The orchid-bee fauna (Hymenoptera: Apidae) of 'Reserva Biológica de Una', a hotspot in the Atlantic Forest of southern Bahia, eastern Brazil
}

\author{
Nemésio, A.* \\ Instituto de Biologia, Universidade Federal de Uberlândia - UFU, Rua Ceará, s/n, Campus Umuarama, \\ CEP 38400-902, Uberlândia, MG, Brazil \\ *e-mail: andre.nemesio@gmail.com
}

Received February 14, 2012 - Accepted August 18, 2012 - Distributed May 31, 2013

\begin{abstract}
The orchid-bee fauna of 'Reserva Biológica de Una' (REBIO Una), one of the largest Atlantic Forest remnants in southern Bahia, eastern Brazil, was surveyed for the first time. Baits with sixteen different scents were used to attract males of orchid bees. Eight hundred and fifty-nine males belonging to 26 species were actively collected with insect nets during 60 hours in January and February, 2009, and January, 2010. Euglossa avicula Dressler, 1982 and Euglossa milenae Bembé, 2007 have been recorded for the first time in the state of Bahia. It was found that REBIO Una has one of the most diverse and rich orchid-bee faunas of the entire Atlantic Forest domain and holds some rare species, such as Euglossa cyanochlora Moure, 1996.
\end{abstract}

Keywords: Atlantic Forest, conservation, Euglossina, euglossine bees, Hexapoda.

\section{A fauna de abelhas-das-orquídeas (Hymenoptera: Apidae) da 'Reserva Biológica de Una', um 'hotspot' na Mata Atlântica do sul da Bahia, leste do Brasil}

\begin{abstract}
Resumo
A fauna de abelhas-das-orquídeas da Reserva Biológica de Una (REBIO Una), um dos maiores remanescentes de Mata Atlântica do sul da Bahia, leste do Brasil, foi amostrada pela primeira vez. Iscas com 16 diferentes fragrâncias atrativas a machos de abelhas-das-orquídeas foram utilizadas. Um número de 859 machos, pertencentes a 26 espécies, foi ativamente coletado com o auxílio de redes entomológicas, durante 60 horas, em janeiro e fevereiro de 2009, e janeiro de 2010. Euglossa avicula Dressler, 1982 e Euglossa milenae Bembé, 2007 foram registradas pela primeira vez no Estado da Bahia. A REBIO Una mostrou possuir uma das mais ricas e diversificadas faunas de abelhas-das-orquídeas de toda a Mata Atlântica, e abriga algumas espécies consideradas raras, como Euglossa cyanochlora Moure, 1996.
\end{abstract}

Palavras-chave: Mata Atlântica, conservação, Euglossina, abelhas euglossinas, Hexapoda.

\section{Introduction}

The Atlantic Forest has been considered one of the earth's biological "hotspots" (Myers, 1988; Mittermeier et al., 1999; Galindo-Leal and Câmara, 2003) and the region of the southern state of Bahia is probably the hottest section of this hotspot (see Laurance, 2009), with the highest levels of endemism for many taxonomic groups (e.g., Dean, 1995; Pacheco et al., 1996; Thomas et al., 1997, 1998; Sambuichi et al., 2008). Nevertheless, most of the original forest cover in southern Bahia was wiped out and only scattered fragments remain (Fundação SOS Mata Atlântica, 1993; Ribeiro et al., 2009), the largest of them not exceeding 25,000 ha (Ribeiro et al., 2009). Species endemic in such fragmented biomes are more prone to population declines and even to extinction. Concerning the Neotropical forest-dependent orchid bees (Hymenoptera: Apidae: Euglossina), Nemésio (2009, 2010a, 2011b) and

Nemésio et al. (2012) have warned that some orchid-bee species with restricted geographical distributions within the Atlantic Forest domain may be severely affected by their habitat loss. It is impossible, however, to make any conclusions about the conservation status of any animal group if even the faunistic composition and actual geographic distribution of its species are little or not at all known.

The 'Reserva Biológica de Una' is one of the largest preserves in the Atlantic Forest of southern Bahia and is reputed to holding astonishingly high diversities and levels of endemism for many taxonomic groups (reviewed by Martini, 2002). There have been only two other surveys for orchid bees in southern Bahia (Melo, 2005; Nemésio, 2011a), but these few collections have revealed a high diversity of new records for the region (Nemésio, 2011a, e; Nemésio et al., 2012) and even new species (e.g., Moure, 
1996; Nemésio 2011b, c, d, 2012). The main goal of this study is to expand distributional and taxonomic knowledge on the orchid bees of the Brazilian Atlantic Forest, with special emphasis to the region of southern Bahia, by providing relevant data on the orchid-bee species found in a previously unsampled area of one of the most threatened biomes in the world.

\section{Material and Methods}

\subsection{Study sites}

This study was conducted at 'Reserva Biológica de Una' (REBIO Una), a 18,000-ha preserve situated in the municipality of Una, in the state of Bahia, eastern Brazil in January and February 2009, and the summer of January 2010, when orchid bees are most actively foraging (e.g., Martins and Souza, 2005). The vegetation of REBIO Una is essentially dense Atlantic Rain Forest [Central Lowland Forest according to Thomas and Carvalho (2003)]. Most of the preserve consists of secondary forests in various successional stages, since pastures, other crops and mainly cocoa plantations happened to take place in the area before the establishment of the preserve in 1979 , but pristine forested areas can also be found at REBIO Una (see Martini, 2002). Precipitation in the area is $c a$. 1,300 mm/year (Thomas and Carvalho, 2003).

\subsection{Sampling}

Twenty hours of active sampling with insect nets were performed in each of the three selected sites in the preserve, totaling 60 hours, following the methodology proposed by Nemésio (2010a, b, 2011a, b): site-1 (15 10' 07' S and 39 03' 54" W, ca. $60 \mathrm{~m}$ above sea level) was sampled on the $29^{\text {th }}$ and $30^{\text {th }}$ of January, 2009, from 08:00h to $15: 00 \mathrm{~h}$ and on the $20^{\text {th }}$ of January, 2010, from 08:00h to $14: 00 \mathrm{~h}$; site-2 (15 $10^{\circ} 26^{\prime \prime} \mathrm{S}$ and $39^{\circ} 03^{\prime} 42^{\prime \prime} \mathrm{W}$, ca. $60 \mathrm{~m}$ above sea level) was sampled on the $28^{\text {th }}$ (from $10: 00 \mathrm{~h}$ to $15: 00 \mathrm{~h}$ ) and the $31^{\text {st }}$ (from $07: 00$ to $16: 00 \mathrm{~h}$ ) of January, 2009, and on the $19^{\text {th }}$ of January, 2010 from 08:00h to $14: 00 \mathrm{~h})$; site-3 (15 $11^{\circ} 00^{\prime}$ ' S and $39^{\circ} 04^{\prime} 01^{\prime \prime} \mathrm{W}$, ca. $50 \mathrm{~m}$ above sea level) was sampled on the $1^{\text {st }}$ and $2^{\text {nd }}$ of February, 2009, from 07:00h to $14: 00 \mathrm{~h}$ and on the $21^{\text {st }}$ of January, 2010, from 07:00h to 13:00h. Sites 1 and 3 were located in areas with pristine, well developed forests. Site 2 , for comparison, was located in an area in early to intermediate successional stage. At each site, 17 scent baits were placed $c a$. 2.0 metres apart from each other at about $1.5 \mathrm{~m}$ above the ground. These baits were made of cotton wadding soaked with one of the following substances, known or believed to be attractive to orchid bees: benzyl acetate, benzyl alcohol, $r$-carvone, 1,8-cineole, $p$-cresol acetate, dimethoxybenzene, eugenol, $\beta$-ionone, methyl benzoate, methyl trans-cinnamate, heneicosane, methyl salicylate, skatole, tricosane, $p$-tolyl acetate, vanillin, and a mixture $(1: 1)$ of methyl trans-cinnamate and $p$-tolyl acetate. Baits with cineole, the most volatile compound, were recharged every hour. Bees arriving on the baits during the sampling period were collected with insect nets and killed with ethyl acetate. They were labelled as belonging to the project "Euglossina da Hileia Baiana" and were deposited at the Entomological Collection of 'Universidade Federal de Minas Gerais' (UFMG), where they were numbered from 17627-50352 to 17718-50681 (specimens collected in 2010) and from 18964-54409 to 19156-54953 (specimens collected in 2009).

\subsection{Data analysis}

Diversity was estimated through Shannon-Wiener diversity index $\left(H^{\prime}\right)$, as $H^{\prime}=-\Sigma p_{i} \ln \left(p_{i}\right)$, where $p_{i}$ is the proportion of the total number of species made up of the ith species (Pielou, 1975). Evenness (E) was estimated through the formula $E=H^{\prime} / \ln (S)$, where $S$ is the species richness. The similarity in faunistic composition among all sites was estimated by the percent similarity index of Renkonen, recommended by Wolda (1981) for small samples. Based on those similarities, the areas were grouped using UPGMA (Sneath and Sokal, 1973).

\subsection{Taxonomy}

Taxonomy follows Nemésio and Rasmussen (2011) with the additions provided by Hinojosa-Díaz et al. (2012), Nemésio (2012) and Nemésio and Engel (2012).

\section{Results}

Eight hundred and fifty-nine orchid-bee males belonging to 26 species in four genera were collected at REBIO Una (Table 1). Euglossa carolina Nemésio, 2009 and Eg. imperialis Cockerell, 1922 were the most abundant species and these two species together represented almost one third of all collected orchid bees (Table 1). Ten species were represented by three or less individuals; consequently, they were not recorded at all three sites (except Eg. liopoda Dressler, 1982 - Table 1). Eleven species were represented by 35 or more specimens, and only one of them, Eg. pleosticta Dressler, 1982, was not present in all three sites (Table 1). The same sampling effort was carried out in all three sites, allowing a direct comparison among their faunistic features. Site 2 presented the lowest abundance ( $c a$. six specimens/hour) and number of species (17) (Table 1), as well as the lowest diversity $\left(\mathrm{H}^{\prime}=2.42\right)$. Twenty-one species were collected in both sites 1 and 3, but abundance was higher in site 3 (22 specimens/hour) than in site 1 (15 specimens/hour). Diversity was almost the same in these two sites (Table 1) as well as evenness, which showed a similar high value in all three sites (Table 1).

The ordination of the sites according to their faunas showed a great overall similarity among the sites. Sites 1 and 3 , situated in the best preserved forest patches, grouped together with ca. $70 \%$ similarity and then grouped to site 2 , with ca. $66 \%$ similarity.

\section{Discussion}

The strategy of intensive sampling using the same methods as employed here, over a few days during the 
Table 1. Diversity, evenness, species richness and number of specimens of each orchid-bee species collected at sites 1 to 3 at 'Reserva Biológica de Una', state of Bahia, eastern Brazil, after 20 hours of sampling in each site.

\begin{tabular}{|c|c|c|c|c|}
\hline fig & Site 1 & Site 2 & Site 3 & Total \\
\hline Eufriesea atlantica Nemésio, 2008 & 2 & 0 & 1 & 3 \\
\hline Euglossa amazonica Dressler, 1982 & 0 & 1 & 0 & 1 \\
\hline Euglossa aratingae Nemésio, 2009 & 2 & 0 & 0 & 2 \\
\hline Euglossa augaspula Hinojosa-Díaz, Nemésio \& Engel, 2012 & 2 & 1 & 8 & 11 \\
\hline Euglossa avicula Dressler, 1982 & 1 & 0 & 0 & 1 \\
\hline Euglossa carolina Nemésio, 2009 & 54 & 27 & 59 & 140 \\
\hline Euglossa clausi Nemésio \& Engel, 2012 & 14 & 8 & 16 & 38 \\
\hline Euglossa cyanochlora Moure, 1996 & 2 & 0 & 4 & 6 \\
\hline Euglossa despecta Moure, 1968 & 10 & 5 & 71 & 86 \\
\hline Euglossa ignita Smith, 1874 & 17 & 4 & 28 & 49 \\
\hline Euglossa imperialis Cockerell, 1922 & 39 & 5 & 93 & 137 \\
\hline Euglossa liopoda Dressler, 1982 & 1 & 1 & 1 & 3 \\
\hline Euglossa marianae Nemésio, 2011b & 8 & 4 & 11 & 23 \\
\hline Euglossa milenae Bembé, 2007 & 1 & 0 & 0 & 1 \\
\hline Euglossa mixta Friese, 1899 & 45 & 5 & 18 & 68 \\
\hline Euglossa monnei Nemésio, 2012 & 0 & 0 & 2 & 2 \\
\hline Euglossa pleosticta Dressler, 1982 & 0 & 12 & 23 & 35 \\
\hline Euglossa roubiki Nemésio, 2009 & 20 & 1 & 15 & 36 \\
\hline Euglossa securigera Dressler, 1982 & 0 & 2 & 1 & 3 \\
\hline Euglossa viridis (Perty, 1833) & 1 & 0 & 0 & 1 \\
\hline Eulaema atleticana Nemésio, 2009 & 22 & 17 & 38 & 77 \\
\hline Eulaema marcii Nemésio, 2009 & 4 & 0 & 5 & 9 \\
\hline Eulaema nigrita Lepeletier, 1841 & 38 & 13 & 26 & 77 \\
\hline Eulaema niveofasciata (Friese, 1899) & 14 & 5 & 16 & 35 \\
\hline Exaerete frontalis (Guérin-Méneville, 1844) & 6 & 4 & 4 & 14 \\
\hline Exaerete smaragdina (Guérin-Méneville, 1844) & 0 & 0 & 1 & 1 \\
\hline Total & 303 & 115 & 441 & 859 \\
\hline Species richness $(\mathrm{S})$ & 21 & 17 & 21 & 26 \\
\hline Shannon-Wiener diversity index (H') & 2.48 & 2.42 & 2.47 & 2.58 \\
\hline Evenness (E) & 0.82 & 0.85 & 0.81 & 0.79 \\
\hline
\end{tabular}

season when orchid bees are most actively foraging, has been demonstrated to be adequate for surveys focusing on this group of bees (Nemésio 2010b, 2011a, b, Nemésio et al., 2012). As pointed out by Nemésio (2010b), twenty hours of sampling during the season when orchid bees are most abundant provides similar results to one year of monthly samplings of three to four hours per sampling (e.g., Rebêlo and Garófalo, 1991, 1997; Santos and Sofia, 2002; Nemésio and Silveira, 2007, 2010). This is because year-round sampling occurs predominantly during less favourable seasons for orchid bees. The high abundance recorded by Nemésio (2010b, 2011a, b, this study) is suggestive of the efficiency of this method, when areas to be sampled are distant and costs of regular visits to each area are very high. Although seasonal fluctuations in the populations of orchid-bee species cannot be measured with this sampling strategy, the faunistic composition and relative abundances of each species that visit the baits can be estimated with reasonable confidence. This may be particularly important in areas that are ill-sampled or have not been sampled at all, and may improve our knowledge on the occurrence and distribution of many species.

Neves and Viana (2003) listed 33 species for the Atlantic Forest of Bahia, but Nemésio (2009, 2011a) showed that some of them are junior synonyms of other species found in the area and other species were misidentifications. The only other studies carried out in southern Bahia are those by Melo (2005), at 'RPPN Estação Veracel', a private preserve belonging to Veracel Celulose in the municipalities of Porto Seguro and Santa Cruz Cabrália, some $100 \mathrm{~km}$ south of REBIO Una, and Nemésio (2011a), at 'Parque Estadual da Serra do Conduru' (PESC), a state preserve in the municipalities of Ilhéus and Uruçuca, some $60 \mathrm{~km}$ north of REBIO Una (see Nemésio 2011a). Nemésio (2011a) compared the list of orchid-bee species of both 'Estação Veracel' and PESC and recognised 26 species occurring 
in southern Bahia from Uruçuca to Santa Cruz Cabrália. Three species collected in the present study (Euglossa avicula Dressler, 1982; Eg. milenae Bembé, 2007; and Eg. monnei Nemésio, 2012), however, were not collected by Melo (2005) or Nemésio (2011a), raising the number of known species in the same area (since REBIO Una lies exactly between both preserves) to 29 . The two former species are here reported for the first time in the state of Bahia. Euglossa monnei had already been listed to Bahia when originally described (see Nemésio 2012). The bee occurring in Bahia listed by Neves and Viana (2003) and Nemésio (2009, 2011a) as Euglossa analis Westwood, 1840 was later recognised as a different species, Euglossa marianae Nemésio, 2011b, and it is hereby treated as such.

Recent surveys of orchid bees have emphasized the occurrence of new species or species not previously known to a given region or area (e.g. Morato, 2001; Nemésio 2010b, 2011a), but equally relevant can be the absence of some species expected to occur in a given area. In this respect, there is a noticeable absence of Euglossa cognata Moure, 1970, a bee known to occur in the Atlantic Forest of Espírito Santo and Minas Gerais (reviewed by Nemésio, 2009) and also listed for the Atlantic Forest of Bahia by Neves and Viana (2003) - although these latter authors did not indicate the exact locality where the examined specimens came from - and Nemésio (2009), for Una and Porto Seguro. Euglossa cognata seems to be a forest-dependent species and Nemésio (2009) suggests it should be considered as vulnerable according to IUCN criteria. The absence of this species in three relatively large forest remnants (PESC, REBIO Una, and RPPN Estação Veracel) in southern Bahia suggests not only that they may be geographically restricted, but also that its population may be declining in areas where it had been previously recorded, a fact already observed for its close ally Eg. marianae (see Nemésio, 2011b, Nemésio, 2013).

Diversity and richness were very similar among the three sampled sites at REBIO Una (Table 1), which is also reflected in the overall similarity among sites. It is noticeable, however, that the similarity among all sites varied from 66 to $69 \%$, a relatively low value when compared to the observed overall similarity among sites situated in different and isolated forest remnants of urban areas (Nemésio and Silveira, 2007, 2010) or among sites situated in a large forest preserve in southeastern Brazil (Nemésio and Silveira, 2006), when similarities of over $80 \%$ were observed. This suggests that either the sampling effort, in spite of resulting in a high number of collected bees, is still not effective enough to thoroughly sample each site or that within-habitat heterogeneity (see Armbruster, 1993) should be considered when sampling areas with higher diversity. Thus, more sampling sites should be selected for these areas to better sample the entire area. It is remarkable and suggestive of the second hypothesis, for example, that Eg. pleosticta was not recorded at site 1, but was relatively common at both sites 2 and 3 (Table 1), in spite of the physiognomic differences between these latter sites.
In spite of the absence of Euglossa cognata, REBIO Una presented the highest richness and diversity not only when compared to PESC and 'Estação Veracel', but also to all other forest preserves in the Atlantic Forest to date, with the possible exception of 'Reserva Natural Vale', in Linhares, state of Espírito Santo (Bonilla-Gómez, 1999). It should be considered, however, that samplings at REBIO Una were carried out in late January and early February, when some species of Eufriesea were not active anymore. Maybe for this reason, only one species of Eufriesea was recorded at REBIO Una in the present study (see Table 1), when it is known that at least two other species occur in the region (see Nemésio 2011a). REBIO Una should also be highlighted for holding some very sensitive forest-dependent species, such as Euglossa marianae and Eg. cyanochlora. It should also be remarked that it is in REBIO Una region that the rare Eg. cyanochlora seems to present the highest genetic variability (see Nemésio et al., 2012).

Similar to many other "protected" natural areas in eastern Brazil, the situation faced by this preserve is problematic (few personnel to patrol the area; presence of hunters and wood dealers; legal problems with former owners of the land; invasion by "alleged" Indians who claim the area). The presence of apparently sensitive orchid-bee species, such as Euglossa marianae (see Tonhasca Junior et al., 2002; Nemésio and Silveira, 2006; Nemésio, 2010b, 2011b), Euglossa roubiki Nemésio, 2009 and Euglossa amazonica Dressler, 1982 (see Nemésio, 2010b, 2011b), besides Euglossa cyanochlora, suggests that this area still holds important habitat for most, if not all, local orchid bees. Nevertheless, if the conservation problems listed above are not solved in the near future, there will be almost nothing to be preserved, due to the accelerated damages caused to the area and the very slow governmental response to this situation.

Acknowledgements - The Brazilian government, through the environmental departments IBAMA and ICMBio, provided the collecting permit (\#18131-8). I express my gratitude to Paulo César Cruz and Saturnino Neto F. Sousa, administrators of REBIO Una, who were very helpful during my field research. One anonymous referee made several suggestions to a first draft of this manuscript, which highly improved it.

\section{References}

ARMBRUSTER, WS., 1993. Within-habitat heterogeneity in baiting samples of male euglossine bees: possible causes and implications. Biotropica, vol. 25, p. 122-128. http://dx.doi. org/10.2307/2388986

BONILLA-GÓMEZ, MA., 1999. Caracterização da Estrutura Espaço-temporal da Comunidade de Abelhas Euglossinas (Hymenoptera, Apidae) na Hiléia Bahiana. Campinas: Universidade Estadual de Campinas. 153 p. Tese de Doutorado em Ecologia.

DEAN, W., 1995. With Broadax and Firebrand - The Destruction of the Brasilian Atlantic Forest. Berkeley: University of California Press.

Fundação SOS Mata Atlântica, 1993. Dossiê Mata Atlântica. São Paulo: Fundação SOS Mata Atlântica. 
GALINDO-LEAL, C. and CÂMARA, IG., 2003. Atlantic Forest hostpot status: an overview. In GALINDO-LEAL, C. \& CÂMARA, IG. (Ed.). The Atlantic Forest of South America: biodiversity status, threats, and outlook. Washington: Island Press. p. 3-11.

HINOJOSA-DÍAZ, IA., NEMÉSIO, A. and ENGEL, MS., 2012. Two new species of Eugossa from South America, with notes on their taxonomic affinities (Hymenoptera, Apidae). ZooKeys, vol. 221, p. 63-79. http://dx.doi.org/10.3897/zookeys.221.3659

LAURANCE, WF., 2009. Conserving the hottest of the hotspots. Biological Conservation, vol. 142, p. 1137. http://dx.doi. org/10.1016/j.biocon.2008.10.011

MARTINI, AMZ., 2002. Estrutura e composição da vegetação e chuva de sementes em sub-bosque, clareiras naturais e área perturbada por fogo em floresta tropical no sul da Bahia. Campinas: Universidade Estadual de Campinas. 138 p. Tese de Doutorado em Ecologia.

MARTINS, CF. and SOUZA, AKP., 2005. Estratificação vertical de abelhas Euglossina (Hymenoptera, Apidae) em uma área de Mata Atlântica, Paraíba, Brasil. Revista Brasileira de Zoologia, vol. 22, p. 913-918. http://dx.doi.org/10.1590/S0101-81752005000400016

MELO, AMC., 2005. Gradientes ambientais e a comunidade de abelhas Euglossina (Hymenoptera, Apidae) em fragmentos de Mata Atlântica intercalados por uma matriz de eucaliptais no extremo sul da Bahia. Salvador: Universidade Federal da Bahia. 116 p. Dissertação de Mestrado em Ecologia e Biomonitoramento.

MITTERMEIER, RA., MYERS, N., GIL, PR. and MITTERMEIER, CG., 1999. Hot spots: Earth's Biologically Richest and Most Endangered Terrestrial Ecoregions. Mexico: CEMEX. 430 p.

MORATO, EF., 2001. Ocorrência de Aglae caerulea Lepeletier \& Serville (Hymenoptera, Apidae, Apini, Euglossina) no estado do Acre, Brasil. Revista Brasileira de Zoologia, vol. 18, p. 10311034. http://dx.doi.org/10.1590/S0101-81752001000300034

MOURE, JS., 1996. Notas sobre algumas espécies de abelhas da Bahia, Brasil (Hymenoptera, Apoidea). Revista Brasileira de Zoologia, vol. 12, p. 467-470.

MYERS, N., 1988. Threatened biotas: "hot spots" in tropical forests. The Environmentalist, vol. 8, p. 187-208. PMid:12322582. http://dx.doi.org/10.1007/BF02240252

NEMÉSIO, A., 2009. Orchid bees (Hymenoptera: Apidae) of the Brazilian Atlantic Forest. Zootaxa, vol. 2041, p. 1-242.

-, 2010a. Eulaema (Apeulaema) felipei sp. n. (Hymenoptera: Apidae: Euglossina): a new forest-dependent orchid bee found at the brink of extinction in northeastern Brazil. Zootaxa, vol. 2424, p. 51-62.

-, 2010b. The orchid-bee fauna (Hymenoptera: Apidae) of a forest remnant in northeastern Brazil, with new geographic records and an identification key to the known species of the Atlantic Forest of northeastern Brazil. Zootaxa, vol. 2656, p. 55-66.

-, 2011a. The orchid-bee fauna (Hymenoptera: Apidae) of a forest remnant in southern Bahia, Brazil, with new geographic records and an identification key to the known species of the area. Zootaxa, vol. 2821, p. 47-54.

-, 2011b. Euglossa marianae sp. n. (Hymenoptera: Apidae): a new orchid bee from the Brazilian Atlantic Forest and the possible first documented local extinction of a forest dependent orchid bee. Zootaxa, vol. 2892, p. 59-68.

-, 2011c. Exaerete salsai sp. n. (Hymenoptera: Apidae): a new orchid bee from eastern Brazil. Zootaxa, vol. 2967, p. 12-20.
-, 2011d. Euglossa bembei sp. n. (Hymenoptera: Apidae): a new orchid bee from the Brazilian Atlantic Forest belonging to the Euglossa cybelia Moure, 1968 species group. Zootaxa, vol. 3006, p. 43-49.

-, 2011e. Rediscovered after forty-two years: the rare orchid bee Eufriesea brasilianorum (Hymenoptera: Apidae) of eastern Brazil. North-Western Journal of Zoology, vol. 7, p. 356-359.

-, 2012. Species of Euglossa Latreille, 1802 (Hymenoptera: Apidae: Euglossina) belonging to the purpurea species group occurring in eastern Brazil, with description of Euglossa monnei sp. n. Zootaxa, vol. 3151, p. 35-52.

-, 2013. Are orchid bees at risk? First comparative survey suggests declining populations of forest-dependent species. Brazilian Journal of Biology, vol. 73, n. 2, p. 367-374.

NEMÉSIO, A., CERÂNTOLA, NCM., VASCONCELOS, HL., NABOUT, JC., SILVEIRA, FA. and DEL LAMA, MA., 2012. Searching for Euglossa cyanochlora Moure, 1996 (Hymenoptera: Apidae), one of the rarest bees in the world. Journal of Insect Conservation, vol. 16, no. 5, p. 745-755. http://dx.doi.org/10.1007/ s10841-012-9459-2

NEMÉSIO, A. and ENGEL, MS., 2012. Three new cryptic species of Eugossa from Brazil (Hymenoptera, Apidae). ZooKeys, vol. 222, p. 47-68. http://dx.doi.org/10.3897/zookeys.222.3382

NEMÉSIO, A. and RASMUSSEN, C., 2011. Taxonomic issues in the orchid bees (Hymenoptera: Apidae: Euglossina), and an updated catalogue. Zootaxa, vol. 3006, p. 1-42.

NEMÉSIO, A. and SILVEIRA, FA., 2006. Edge effects on the orchid-bee fauna (Hymenoptera: Apidae) at a large remnant of Atlantic Forest in southeastern Brazil. Neotropical Entomology, vol. 35, p. 313-323. PMid:18575690. http://dx.doi.org/10.1590/ S1519-566X2006000300004

-, 2007. Orchid bee fauna (Hymenoptera: Apidae: Euglossina) of Atlantic Forest fragments inside an urban area in southeastern Brazil. Neotropical Entomology, vol. 36, p. 186-191. PMid:17607450. http://dx.doi.org/10.1590/S1519-566X2007000200003

-, 2010. Forest fragments with larger core areas better sustain diverse orchid bee faunas (Hymenoptera: Apidae: Euglossina). Neotropical Entomology, vol. 39, p. 555-561. PMid:20877991. http://dx.doi.org/10.1590/S1519-566X2010000400014

NEVES, EL. and VIANA, BF., 2003. A fauna de abelhas da subtribo Euglossina (Hymenoptera: Apidae) do estado da Bahia, Brasil. In MELO, GAR. and ALVES-DOS-SANTOS, I. (Ed.). Apoidea Neotropica: Homenagem aos 90 anos de Jesus Santiago Moure. Criciúma: Universidade do Extremo Sul Catarinense. p. 223-229.

PACHECO, JF., WHITNEY, BM. and GONZAGA, LP., 1996. A new genus and species of furnariid (Aves: Furnariidae) from the cocoa-growing region of southeastern Bahia, Brazil. The Wilson Bulletin, vol. 108, p. 397-433.

PIELOU, EC., 1975. Ecological diversity. New York: John Wiley \& Sons. 165 p.

REBÊLO, JMM. and GARÓFALO, CA., 1991. Diversidade e sazonalidade de machos de Euglossini (Hymenoptera, Apidae) e preferência por iscas odores em um fragmento de floresta no sudeste do Brasil. Revista Brasileira de Biologia, vol. 51, p. 787-799.

-, 1997. Comunidades de machos de Euglossinae (Hymenoptera, Apidae) em matas semidecíduas do nordeste do estado de São Paulo. Anais da Sociedade Entomológica do Brasil, vol. 26, p. 243-256. http://dx.doi.org/10.1590/S0301-80591997000200005 
RIBEIRO, MC., METZGER, JP., MARTENSEN, AC., PONZONI, FJ. and HIROTA, MM., 2009. The Brazilian Atlantic Forest: how much is left, and how is the remaining forest distributed? Implications for conservation. Biological Conservation, vol. 142, p. 114-1153.

SAMBUICHI, RHR., OLIVEIRA, RM., MARIANO NETO, E., THÉVENIN, JMR., JESUS JUNIOR, CP., OLIVEIRA, RL. and PELIÇÃO, LC., 2008. Status de conservação de dez árvores endêmicas da Floresta Atlântica do sul da Bahia-Brasil. Natureza \& Conservação, vol. 6, p. 90-108.

SANTOS, AM. and SOFIA, SH., 2002. Horário de atividade de machos de Euglossinae (Hymenoptera, Apidae) em um fragmento de floresta semidecídua no norte do estado do Paraná. Acta Scientiarum, vol. 24, p. 375-381.

SNEATH, PHA. and SOKAL, RR., 1973. Numerical taxonomy: The principles and practice of numerical classification, San Francisco: W. H. Freeman. 573 p.

THOMAS, WW. and CARVALHO, AM., 2003. Zoneamento Ecológico do Sudeste da Bahia, Brasil (mapa em formato digital). In PRADO, PI., LANDAU, EC., MOURA, RT., PINTO, LPS., FONSECA, GAB. \& ALGER, K. (Orgs.). Corredor de Biodiversidade da Mata Atlântica do Sul da Bahia. Ilhéus: IESB/ Conservation International. Published in CD-ROM.
THOMAS, WW., CARVALHO, AM., AMORIM, AMA., GARRISON, J. and ABERLÁEZ, AL., 1998. Plant endemism in two forests in southern Bahia. Biodiversity and Conservation, vol. 7, p. 311-322. http://dx.doi.org/10.1023/A:1008825627656

THOMAS, WW., CARVALHO, AM. and HERRERA-MACBRYDE, O., 1997. Atlantic moist forest of southern Bahia: South-eastern Brazil. In World Wide Fund for Nature - WWF and International Union for Conservation of Nature - IUCN. Centers of plant diversity: A guide and strategy for their conservation. Cambridge: IUCN Publications Unit. Vol. 3, p. 364-368.

TONHASCA JUNIOR, A., BLACKMER, JL. and ALBUQUERQUE, GS., 2002. Abundance and diversity of euglossine bees in the fragmented landscape of the Brazilian Atlantic Forest. Biotropica, vol. 34, p. 416-422.

WESTWOOD, JO., 1840. Entomology [Vol. 6]. Bees, comprehending the uses and economical management of the honey-bee of Britain and other countries, together with descriptions of the known wild species. In JARDINE, W. (Ed.). The naturalist's library. Edinburgh: W.H. Lizars. 301 p.

WOLDA, H., 1981. Similarity indices, sample sizes and diversity. Oecologia, vol. 50, p. 296-302. http://dx.doi.org/10.1007/ BF00344966 